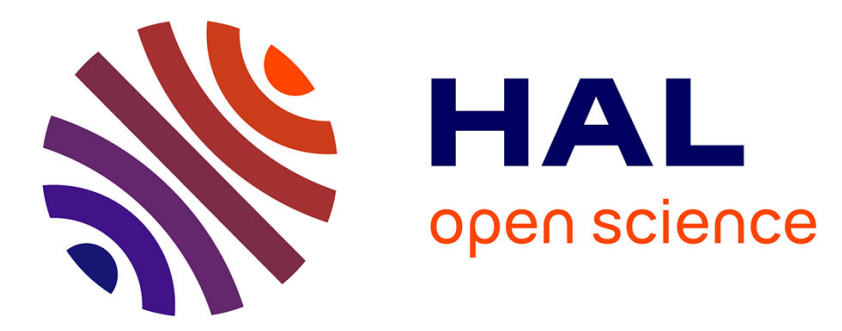

\title{
( \pm -1,1'-Binaphtalene-2,2'-diol-derived phosphoric diester: immobilization on polyethylene glycol support and application in the Pudovik reaction
}

\author{
I.P. Beletskaya, L.S. Patrikeeva, Frédéric Lamaty
}

\section{To cite this version:}

I.P. Beletskaya, L.S. Patrikeeva, Frédéric Lamaty. ( \pm -1,1'-Binaphtalene-2,2'-diol-derived phosphoric diester: immobilization on polyethylene glycol support and application in the Pudovik reaction. Russian Chemical Bulletin, 2011, 60 (11), pp.2370-2374. 10.1007/s11172-011-0364-8 . hal-00728973

\author{
HAL Id: hal-00728973 \\ https://hal.science/hal-00728973
}

Submitted on 3 Feb 2021

HAL is a multi-disciplinary open access archive for the deposit and dissemination of scientific research documents, whether they are published or not. The documents may come from teaching and research institutions in France or abroad, or from public or private research centers.
L'archive ouverte pluridisciplinaire HAL, est destinée au dépôt et à la diffusion de documents scientifiques de niveau recherche, publiés ou non, émanant des établissements d'enseignement et de recherche français ou étrangers, des laboratoires publics ou privés. 


\title{
( \pm )-1,1'-Binaphthalene-2,2'-diol-derived phosphoric diester: immobilization on polyethylene glycol support and application in the Pudovik reaction*
}

\author{
I. P. Beletskaya, ${ }^{a \star}$ L. S. Patrikeeva, ${ }^{a, b}$ and F. Lamaty ${ }^{b}$ \\ ${ }^{a} M$. V. Lomonosov Moscow State University, Department of Chemistry, \\ str. 3, 1 Leninskie gory, 119991 Moscow, Russian Federation. \\ Fax: +7(495) 939 3618. E-mail: beletska@org.chem.msu.ru \\ ${ }^{b}$ Max Mousseron Institute of Biomolecules (IBMM), Montpellier University 2, \\ cc1703 Place Eugene Bataillon, 34095 Montpellier Cedex 05, France**
}

\begin{abstract}
$( \pm)-1,1^{\prime}$-Binaphthalene-2,2' -diol (BINOL) was immobilized on polyethylene glycol (PEG) by means of triazole linkers, which were constructed by the [3+2] cycloaddition between azide and ethynyl fragments, preliminary incorporated into the molecules of these reactants. Treatment of these BINOL derivatives with phosphorus oxychloride leads to the corresponding PEG-immobilized 1,1'-binaphthalene-2,2'-diylphosphoric acids. The latter efficiently catalyze the Pudovik reaction and can be reused without loss of catalytic activity.
\end{abstract}

Key words: $( \pm)$-BINOL, phosphoric acids, polyethylene glycol, $\alpha$-aminophosphonates, the Pudovik reaction, recyclization.

One of the most widely used methods for the preparation of $\alpha$-aminophosphonates is the Pudovik reaction, ${ }^{\mathbf{1}-\mathbf{3}}$ which is commonly catalyzed by Lewis ${ }^{\mathbf{4 - 9}}$ or Brønsted ${ }^{\mathbf{1 0}}$ acids. An asymmetric version of this reaction is especially important. Its successful accomplishment using a sophisticated complex compound as a Lewis acid ${ }^{\mathbf{1 1}}$ allowed one to obtain $\alpha$-aminophosphonates with enantiomeric excess up to $96 \%$.

However, in the last years no less successful results were obtained with more simple and available organic catalysts and especially with diesters of phosphoric acid based on 1,1'-binaphthalene-2,2'-diol (BINOL). ${ }^{\mathbf{1 2}}$ It is of note that reactions catalyzed by organic compounds require high enough concentrations of a chiral catalyst, which brings up the problem of its recovery.

At the present time, in asymmetric synthesis ${ }^{\mathbf{1 3}}$ much attention is being paid to polymer-supported catalysts, in particular, to their isolation and recyclization. The choice of a polymer plays a decisive role in homogenization of the medium. Such polymers as polyethylene glycol (PEG) and polystyrene are of wide application here, ${ }^{\mathbf{1 4}}$ since they are soluble in most organic solvents, for example, in dichloromethane, chloroform, and tetrahydrofuran.

\footnotetext{
* Dedicated to Academician of the Russian Academy of Sciences O. M. Nefedov on the occasion of his 80th birthday.

** Institut des Biomolécules Max Mousseron (IBMM), Université Montpellier 2, Place Eugène Bataillon cc1703, 34095 Montpellier Cedex 05 France.
}

In the present work, we accomplished immobilization of $( \pm)-1,1^{\prime}$-binaphthalene-2,2'-diylphosphoric acid on PEG and studied a possibility for the thus obtained organocatalysts to be reused in the Pudovik reaction.

\section{Results and Discussion}

( \pm )-1,1'-Binaphthalene-2,2'-diylphosphoric acid immobilized on the PEG monomethyl ether was synthesized by two different ways (Scheme 1) based on [3+2] cycloaddition of azides to alkynes. This led to obtaining of two catalysts, which, as it was established later, exhibit different catalytic activity.

The catalyst synthesis included bromination of compound 1 (see Refs 15 and 16) and then obtaining terminal acetylene $\mathbf{3} \mathbf{a}$ and azide $\mathbf{3 b}$ as described. ${ }^{\mathbf{1 7}, \mathbf{1 8}}$ The key step was a connection of BINOL to the polymeric support, which was carried out using a $\mathrm{Cu}^{\mathrm{I}}$-catalyzed [3+2] cycloaddition of azides to terminal acetylenes ("click chemistry"). It should be noted that in the first case, the 1,2,3-triazole fragment was formed by cycloaddition of the BINOL derivative 3a bearing a triple bond and azidopolyethylene glycol 4a. In the second case, immobilization was carried out by connection of azide $\mathbf{3 b}$ to PEG $\mathbf{4 b}$ bearing a propargyl group. It is necessary to emphasize that the literature has no reports on the use of "click chemistry" for immobilization of BINOL. In the present work, PEG $\left(\mathrm{M}_{\mathrm{w}}=5000 \mathrm{Da}\right)$ was chosen as the polymeric support because of its good 
Scheme 1<smiles>Oc1ccc2ccccc2c1-c1c(O)ccc2cc(Br)ccc12</smiles>

2

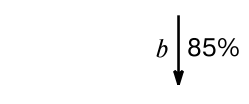<smiles>C#Cc1ccc2c(-c3c(O)ccc4ccccc34)c(O)ccc2c1</smiles>

3a<smiles>CON(C)c1cc(-c2ccc3c(-c4c(O)ccc5ccccc45)c(O)ccc3c2)nnn1</smiles>

$d \downarrow 95 \%$<smiles>O=P1(O)Oc2ccc3ccccc3c2-c2c(ccc3cc(-c4cn(CO)nn4)ccc23)O1</smiles><smiles>Oc1ccc2ccccc2c1-c1c(O)ccc2ccccc12</smiles>

1

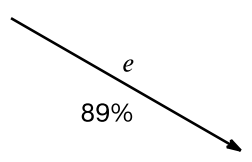<smiles>N#[N+]c1ccc2c(-c3c(O)ccc4ccccc34)c(O)ccc2c1</smiles>

3b

$$
\mathrm{O}_{\mathbf{4 b}} \underset{95 \%}{c}
$$

MeO-PEG ${ }_{5000}$

Reagents and conditions: $a$. 1) $\mathrm{Bu}^{\mathrm{t}} \mathrm{COCl}, \mathrm{Et}_{3} \mathrm{~N}, \mathrm{Py}, \mathrm{THF}, 0{ }^{\circ} \mathrm{C}$; 2) $\mathrm{Br}_{2}, \mathrm{MeCN} /$ toluene; 3) $\mathrm{NaHSO}_{3}$; 4) $\mathrm{NaOH}, \mathrm{MeOH} / \mathrm{H}_{2} \mathrm{O}, 10 \mathrm{~h}$, $\left.\left.20^{\circ} \mathrm{C} ; b .1\right) \mathrm{Me}_{3} \mathrm{SiC} \equiv \mathrm{CH}, \mathrm{PdCl}_{2}\left(\mathrm{PPh}_{3}\right)_{2}, \mathrm{CuI}, \mathrm{Et}_{3} \mathrm{~N}, 2 \mathrm{~h}, \mathrm{MW} ; 2\right) \mathrm{KOH}, \mathrm{MeOH} / \mathrm{H}_{2} \mathrm{O}, 10 \mathrm{~h}, 20^{\circ} \mathrm{C} ; c . \mathrm{CuI} \mathrm{Et}_{3} \mathrm{~N}, \mathrm{CH}_{2} \mathrm{Cl}_{2}, 1.5 \mathrm{~h}, 90{ }^{\circ} \mathrm{C}$, $\mathrm{MW}$; d. 1) $\mathrm{POCl}_{3}, \mathrm{Et}_{3} \mathrm{~N}, \mathrm{CH}_{2} \mathrm{Cl}_{2}, 20 \mathrm{~h}, 20^{\circ} \mathrm{C}$; 2) $\mathrm{H}_{2} \mathrm{O}$; e. $\mathrm{NaN}_{3}$, CuI, $\mathrm{MeNHCH}_{2} \mathrm{CH}_{2} \mathrm{NHMe}, 2 \mathrm{~h}, 100{ }^{\circ} \mathrm{C}, \mathrm{MW}$.

$\mathrm{MW}$ is the microwave irradiation

solubility in most organic solvents and water, as well as due to its easy isolation by precipitation with diethyl ether. A procedure ${ }^{19}$ of $[3+2]$ cycloaddition involving the $\mathrm{PEG}_{5000}$ propargyl derivative was modified: the common heating was replaced by microwave irradiation, that allowed us to considerably shorten the reaction time. It should be noted 
that the use of microwave irradiation for the $\mathrm{Cu}^{\mathrm{I}}$-catalyzed [3+2] cycloaddition is described in the literature, including the case of the preparation of macromolecules. ${ }^{20-23}$ The thus obtained immobilized BINOL derivatives $\mathbf{5 a}$ and $\mathbf{5 b}$ were isolated in virtually quantitative yields, 96 and $95 \%$, respectively. The final step consisted of the preparation of phosphoric diesters $\mathbf{6 a}$ and $\mathbf{6 b}$ by phosphorylation with phosphorus oxychloride and was accomplished in high yields, 95 and $97 \%$, respectively.

The thus obtained catalysts $\mathbf{6 a}$ and $\mathbf{6 b}$ were tested in the Pudovik reaction. Addition of diethyl phosphite at $\mathrm{N}$-benzylideneaniline was chosen as the model reaction (Scheme 2).

Scheme 2

$$
\prod_{\mathrm{Ph}^{-N}}^{\mathrm{Ph}}+\mathrm{EtO}_{2} \mathrm{P}(\mathrm{O}) \mathrm{H} \longrightarrow \mathrm{PhHN}_{7}^{\mathrm{Ph}} \overbrace{\mathrm{P}_{\mathrm{OEt}}^{\prime \prime}-\mathrm{OEt}}^{\mathrm{O}}
$$

Conditions: the catalyst: $\mathbf{6 a}$ or $\mathbf{6 b}(10 \mathrm{~mol} . \%)$; the solvent: toluene or $\mathrm{CH}_{2} \mathrm{Cl}_{2}$.

Catalyst 6a was essentially inactive in toluene at room temperature (Table 1, entry 1 ). Heating the reaction mixture at $30^{\circ} \mathrm{C}$ for $8 \mathrm{~h}$ led to $\alpha$-aminophosphonate 7 in $44 \%$ yield (entry 2), whereas the use of microwave irradiation allowed us to increase the product yield to $80 \%$ (entry 3). On moving to dichloromethane as the solvent, the yield of $\alpha$-aminophosphonate 7 was $80 \%$ even if the reaction was carried out at $20{ }^{\circ} \mathrm{C}$ and virtually did not change from cycle to cycle (entry 4). Probably, this was due to the

Table 1. The Pudovik reaction conditions and the yields of $\alpha$-aminophosphonate 7

\begin{tabular}{|c|c|c|c|c|c|c|}
\hline Entry & $\begin{array}{l}\text { Cata- } \\
\text { lyst }\end{array}$ & Solvent & $T /{ }^{\circ} \mathrm{C}$ & $\tau / \mathrm{h}$ & Cycle & $\begin{array}{c}\text { Yield of } \\
\text { product } \\
7(\%)\end{array}$ \\
\hline 1 & $6 a$ & Toluene & 20 & 48 & 1 & 0 \\
\hline 2 & $6 \mathbf{a}$ & Toluene & 30 & 8 & 1 & 44 \\
\hline 3 & $6 \mathbf{a}$ & $\begin{array}{c}\text { Toluene } \\
\text { MW }(200 \mathrm{~W})\end{array}$ & & 0.7 & 1 & 80 \\
\hline 4 & $6 a$ & Dichloromethane & 20 & 10 & $\begin{array}{l}1 \\
2 \\
3\end{array}$ & $\begin{array}{l}79 \\
73 \\
80\end{array}$ \\
\hline 5 & $6 \mathrm{~b}$ & Toluene & 20 & 10 & $\begin{array}{l}1 \\
2 \\
3\end{array}$ & $\begin{array}{l}92 \\
89 \\
87\end{array}$ \\
\hline 6 & 6b & Dichloromethane & 20 & 6 & $\begin{array}{l}1 \\
2 \\
3\end{array}$ & $\begin{array}{l}>99 \\
95 \\
96\end{array}$ \\
\hline
\end{tabular}

better solubility of catalyst 6a in dichloromethane as compared to toluene. Separation of the catalyst from the reaction mixture for the use in the next cycle was accomplished by its precipitation with diethyl ether with subsequent filtration off.

As compared to the catalyst $6 \mathbf{a}$, its analog $6 \mathbf{b}$ proved to be more efficient: the yields of $\alpha$-aminophosphonate 7 were $87-99 \%$. In this case, in both toluene and dichloromethane no significant decrease in the product yields was observed after three cycles (see Table 1, entries 5 and 6 ). To sum up, both catalysts $\mathbf{6 a}$ and $\mathbf{6 b}$ can be reused several times virtually without loss in their activity.

Organocatalysts $\mathbf{6 a}$ and $\mathbf{6 b}$ were studied by scanning electron microscopy (SEM), that allowed us to describe their morphology. As it is seen from the given photographs (Fig. 1), the catalyst 6a consists of agglomerates, whereas the catalyst $\mathbf{6 b}$ resembles a sponge. These microphotographs allow us to draw conclusions on accessibility of the acidic catalytic centers. The catalytic centers of compound $\mathbf{6 b}$ are more available than the catalytic centers of compound $\mathbf{6 a}$, which is apparently responsible for the difference in their catalytic activity.

As it should have been expected, enantioselectivity of organocatalysts, obtained (see Scheme 1) starting from the optically active (R)-BINOL, is not very high, which is attributed to the high stereoavailability of the acid centers.
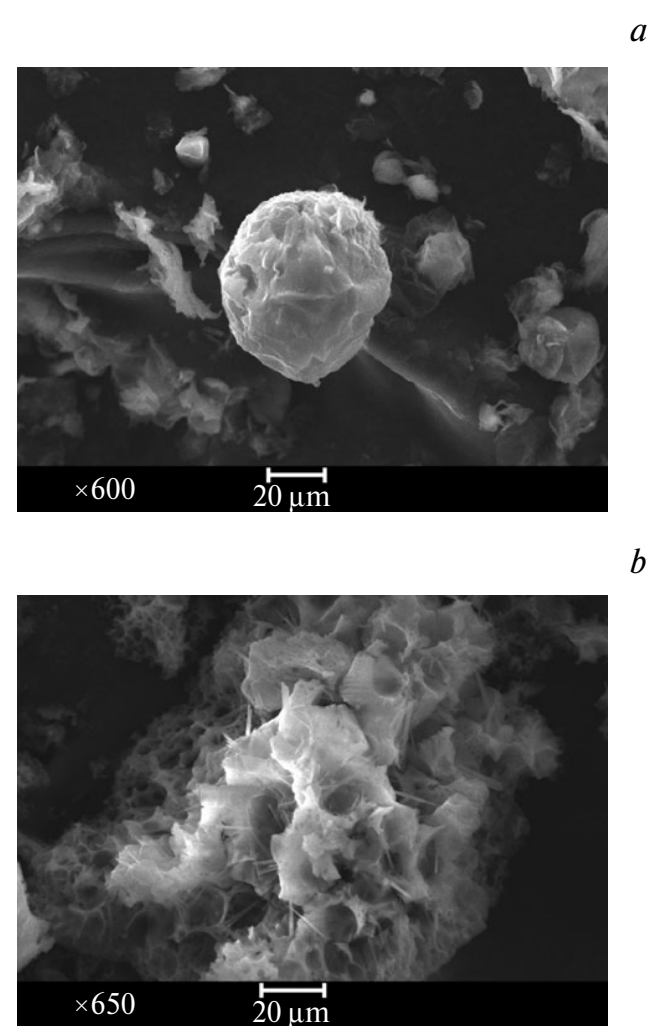

Fig. 1. Electron microphotographs $(25 \mathrm{kV})$ of the catalysts $6 \mathbf{6}(a)$ and $\mathbf{6 b}(b)$. 
It is known that (R)-BINOL-derived phosphoric diester provide high enantioselectivity if they are 3,3'-disubstituted, for example, 3,5-bis(trifluoromethyl)phenyl derivative. ${ }^{11,12}$ As a continuation of the present studies, we are planning this type of immobilization for such Brønsted acids. However, their synthesis is complicated by the necessity not only to introduce substituents at ortho-position to the acid catalytic center, but also to carry out bromination at position 6 for their further addition to a polymeric support.

\section{Experimental}

${ }^{31} \mathrm{P},{ }^{1} \mathrm{H}$, and ${ }^{13} \mathrm{C}$ NMR spectra were recorded on a Bruker Avance-400 spectrometer $\left(161.98\left({ }^{31} \mathrm{P}\right), 400.13\left({ }^{1} \mathrm{H}\right)\right.$, and 100.61 $\left.\left({ }^{13} \mathrm{C}\right) \mathrm{MHz}\right)$ in $\mathrm{CDCl}_{3}$ and DMSO- $\mathrm{d}_{6}$ using signals of the solvents as references: $\mathrm{CHCl}_{3}\left(\delta_{\mathrm{H}} 7.24, \delta_{\mathrm{C}} 76.90\right)$, DMSO $\left(\delta_{\mathrm{H}} 2.50\right.$, $\left.\delta_{\mathrm{C}} 39.50\right)$. IR spectra were recorded on a UR-20 spectrometer $\left(690-3600 \mathrm{~cm}^{-1}\right)$. Elemental analysis was performed on a Carlo Erba CHN-analyzer (the 1106 model, Italy). Experiments using microwave irradiation were carried out in a Biotage Initiator 60 EXP microwave oven. Reaction progress was monitored by TLC on Silufol UV-254 plates and by HPLC on a Waters Millenium 717 chromatograph with a multiwave detector on a diode matrix using Chromolith RP18 columns $(50-4.6 \mathrm{~mm})$. Samples of catalysts $\mathbf{6 a}$ and $\mathbf{6 b}$ were studied by scanning electron microscopy on a JEOL JSM 6490 LV instrument. Preparative column chromatography was performed using Merck 60 silica gel $(0.040-0.063 \mathrm{~mm})$. Polyethylene glycol monomethyl ether with the mass $5000 \mathrm{Da}$ (Fluka) was modified to $\mathbf{4 a}$ and $\mathbf{4 b}$ according to the known procedures. ${ }^{24,25}$ The ${ }^{1} \mathrm{H}$ NMR spectrum $\left(\mathrm{CDCl}_{3}\right)$ of $\mathrm{PEG}_{5000}$ has persistent signals in the region $\delta 3.37(\mathrm{MeO})$ and $3.43-3.83\left(\mathrm{CH}_{2} \mathrm{CH}_{2}\right)$. All the reactions were carried out in anhydrous solvents under dry nitrogen.

( \pm )-6-Bromo-1,1'-binaphthalene-2,2'-diol (2) was obtained according to the known procedure ${ }^{15,16}$ and its physicochemical constants agreed with the literature data.

( \pm )-6-Ethynyl-1,1'-binaphthalene-2,2'-diol (3a). A mixture of 6-bromo-1,1'-binaphthalene-2,2'-diol (2) (1 mmol), trimethylsilylacetylene (1.5 mmol), $\mathrm{CuI}(0.02 \mathrm{mmol}), \mathrm{Pd}\left(\mathrm{PPh}_{3}\right)_{2} \mathrm{Cl}_{2}$ $(0.04 \mathrm{mmol})$ and triethylamine $(3 \mathrm{~mL})$ was subjected to the microwave irradiation $\left(110^{\circ} \mathrm{C}, 400 \mathrm{~W}\right)$ in a 5 -mL sealed reactor with stirring over $2 \mathrm{~h}$ until compound $\mathbf{2}$ was completely consumed (HPLC monitoring). After cooling to room temperature, the reaction mixture was filtered through celite, the product was extracted with AcOEt and washed with brine. The organic phase was dried with $\mathrm{Na}_{2} \mathrm{SO}_{4}$, the solvent was evaporated in vacuo. The residue was dissolved in methanol $(1 \mathrm{~mL})$, followed by addition of $1.5 \mathrm{M}$ aqueous $\mathrm{KOH}(3 \mathrm{~mL})$, and the mixture was stirred at room temperature for $4 \mathrm{~h}$. Then, methanol was evaporated, $1 \mathrm{M}$ aq. $\mathrm{HCl}$ was added to the residue to $\mathrm{pH} 4-5$. The product was extracted with AcOEt, the organic phase was washed with brine, dried with $\mathrm{Na}_{2} \mathrm{SO}_{4}$, the solvent was evaporated in vacuo. The product was purified by column chromatography, using cyclohexane-AcOEt $(9: 1)$ as an eluent. Product $\mathbf{3 a}$ was obtained as white amorphous compound in $85 \%$ yield, $R_{\mathrm{f}}=0.26$ (cyclohexane-AcOEt, $10: 1) .{ }^{1} \mathrm{H}$ NMR $\left(\mathrm{CDCl}_{3}\right), \delta: 3.09(\mathrm{~s}, 1 \mathrm{H})$; $5.22(\mathrm{~s}, 2 \mathrm{H}) ; 7.06(\mathrm{~m}, 3 \mathrm{H}) ; 7.23(\mathrm{~d}, 1 \mathrm{H}, J=6.6 \mathrm{~Hz}) ; 7.25$ $(\mathrm{d}, 1 \mathrm{H}, J=6.6 \mathrm{~Hz}) ; 7.80$ (t, $3 \mathrm{H}, J=6.6 \mathrm{~Hz}) ; 7.85(\mathrm{~d}, 2 \mathrm{H}, J=9 \mathrm{~Hz})$; $7.97(\mathrm{~s}, 1 \mathrm{H}) .{ }^{13} \mathrm{C} \mathrm{NMR}\left(\mathrm{CDCl}_{3}\right), \delta: 77.50,84.00,110.18,111.25$, $117.78,118.28,118.93,123.99,124.19,126.11,127.66,128.49$, $129.47,130.36,130.44,130.58,130.69,131.70,132.01,133.27$, $152.72,153.00$. Found (\%): C, 85.37; H, 4.58. $\mathrm{C}_{22} \mathrm{H}_{14} \mathrm{O}_{2}$. Calculated (\%): C, 85.14; H, 4.55.

( \pm )-6-Azido-1,1' -binaphthalene-2,2'-diol (3b). A mixture of 6-bromo-1,1'-binaphthalene-2,2'-diol (2) (1 mmol), $\mathrm{NaN}_{3}$ (2 mmol), CuI $(0.1 \mathrm{mmol}), N, N^{\prime}$-dimethylethylenediamine $(0.15 \mathrm{mmol})$, and $\mathrm{EtOH}-\mathrm{H}_{2} \mathrm{O}(7: 3)(2 \mathrm{~mL})$ was subjected to the microwave irradiation $\left(110{ }^{\circ} \mathrm{C}, 400 \mathrm{~W}\right)$ in a $2-\mathrm{mL}$ sealed reactor with stirring over $2 \mathrm{~h}$ until compound 2 was completely consumed (HPLC monitoring). After cooling to room temperature, the product was extracted with AcOEt and washed with brine. The organic phase was dried with $\mathrm{Na}_{2} \mathrm{SO}_{4}$, the solvent was evaporated in vacuo. The product was purified by column chromatography, using cyclohexane-AcOEt $(9: 1)$ as an eluent. Product 3b was obtained as amorphous light yellow compound in $89 \%$ yield, $R_{\mathrm{f}}=0.28$ (cyclohexane-AcOEt, $10: 1$ ). ${ }^{1} \mathrm{H}$ NMR $\left(\mathrm{CDCl}_{3}\right), \delta: 4.91(\mathrm{~s}, 2 \mathrm{H}) ; 6.92(\mathrm{~d}, 1 \mathrm{H}, J=8.8 \mathrm{~Hz})$; $7.10(\mathrm{~m}, 2 \mathrm{H}) ; 7.33(\mathrm{~m}, 4 \mathrm{H}) ; 7.46(\mathrm{~d}, 1 \mathrm{H}, J=2.2 \mathrm{~Hz}) ; 7.85$ $(\mathrm{t}, 2 \mathrm{H}, J=8.9 \mathrm{~Hz}) ; 7.91(\mathrm{~d}, 1 \mathrm{H}, J=8.2 \mathrm{~Hz}) .{ }^{13} \mathrm{C}$ NMR $\left(\mathrm{CDCl}_{3}\right), \delta: 110.18,111.25,117.78,118.93,123.99,124.19$, $126.11,127.66,128.49,129.47,130.36,130.44,130.58,130.69$, $131.70,132.01,133.27,137.37,152.72,153.00 . \mathrm{IR}\left(\mathrm{CHCl}_{3}\right)$, v/cm-1: $2110\left(\mathrm{~N}_{3}\right)$. Found (\%): C, 73.15; H, 4.18; N, 13.01. $\mathrm{C}_{20} \mathrm{H}_{13} \mathrm{~N}_{3} \mathrm{O}_{2}$. Calculated (\%): C, 73.38; H, 4.00; N, 12.84 .

4-(2,2'-Dihydroxy-1, $1^{\prime}$-binaphthalen-6-yl)-1 H-1,2,3-triazole attached to $\mathrm{PEG}_{5000}$ monomethyl ether at position 1 (5a). A mixture of 6-ethynyl-1,1'-binaphthalene-2,2' -diol (3a) $(1 \mathrm{mmol}), \mathrm{CuI}(0.05 \mathrm{mmol})$, triethylamine $(0.1 \mathrm{~mL})$, and azido$\mathrm{PEG}_{5000} 4 \mathrm{a}(1 \mathrm{mmol})$ in $\mathrm{CH}_{2} \mathrm{Cl}_{2}(5 \mathrm{~mL})$ was subjected to the microwave irradiation $\left(90^{\circ} \mathrm{C}, 400 \mathrm{~W}\right)$ in a 10 -mL sealed reactor with stirring over $1.5 \mathrm{~h}$ until compound $3 \mathrm{a}$ was completely consumed (HPLC monitoring). After cooling to room temperature, the reaction mixture was treated with $\mathrm{Et}_{2} \mathrm{O}$, a polymer 5a that formed was separated by filtration, washed with $\mathrm{Et}_{2} \mathrm{O}$, and dried in vacuo. The yield was $95 \% .{ }^{1} \mathrm{H}$ NMR $\left(\mathrm{CDCl}_{3}\right), \delta: 4.59(\mathrm{~s}, 2 \mathrm{H}$, $\left.\mathrm{CH}_{2} \mathrm{~N}\right) ; 7.12-7.95$ (m, $\left.11 \mathrm{H}, \mathrm{Ar}\right) ; 8.13$ (s, $\left.1 \mathrm{H}, \mathrm{H}(5)\right)$.

1-(2,2'-Dihydroxy-1,1'-binaphthalen-6-yl)-1 H-1,2,3-triazole attached to PEG $_{5000}$ monomethyl ether at position 4 (5b) was obtained similarly. The yield was 95\%. ${ }^{1} \mathrm{H}$ NMR $\left(\mathrm{CDCl}_{3}\right), \delta$ : 3.83 (s, $2 \mathrm{H}) ; 4.77$ (s, $\left.2 \mathrm{H}, \mathrm{CH}_{2} \mathrm{~N}\right) ; 7.08-7.99$ (m, $\left.11 \mathrm{H}, \mathrm{Ar}\right)$; $8.22(\mathrm{~s}, 1 \mathrm{H}, \mathrm{H}(5))$.

4-(4-Hydroxy-4-oxodinaphtho[1,2-f:2', $\left.1^{\prime}-d\right][1,3,2]$ dioxaphosphepin-9-yl)-1H-1,2,3-triazole attached to PEG $_{5000}$ monomethyl ether at position 1 (6a). Phosphorus oxychloride $(1.5 \mathrm{mmol})$ was added to a solution of compound $\mathbf{5 a}(1 \mathrm{mmol})$ and triethylamine $(0.3 \mathrm{~mL})$ in $\mathrm{CH}_{2} \mathrm{Cl}_{2}(5 \mathrm{~mL})$ with stirring. The reaction mixture was refluxed for $1 \mathrm{~h}$, followed by addition of water $(0.1 \mathrm{~mL})$ and stirring at $20^{\circ} \mathrm{C}$ for $12 \mathrm{~h}$. Then, the mixture was treated with $\mathrm{Et}_{2} \mathrm{O}$. A polymer $\mathbf{6 a}$ that formed was filtered off, washed with $\mathrm{Et}_{2} \mathrm{O}$, and dried in vacuo. The yield was $95 \%$. ${ }^{1} \mathrm{H} \mathrm{NMR}\left(\mathrm{CDCl}_{3}\right), \delta: 4.59\left(\mathrm{~s}, 2 \mathrm{H}, \mathrm{CH}_{2} \mathrm{~N}\right) ; 7.12-7.95(\mathrm{~m}, 11 \mathrm{H}$, Ar); 8.13 (s, $1 \mathrm{H}, \mathrm{H}(5)) .{ }^{31} \mathrm{P}$ NMR (DMSO-d 6 ), $\delta: 3.5$.

1-(4-Hydroxy-4-oxodinaphtho[1,2-f:2',1'-d][1,3,2]dioxaphosphepin-9-yl)-1H-1,2,3-triazole attached to PEG $_{5000}$ monomethyl ether at position 4 (6b) was obtained similarly. The yield was $97 \% .{ }^{1} \mathrm{H}$ NMR $\left(\mathrm{CDCl}_{3}\right), \delta: 4.91(\mathrm{~s}, 2 \mathrm{H}) ; 6.92(\mathrm{~d}, 1 \mathrm{H}$, $J=8.8 \mathrm{~Hz}) ; 7.10(\mathrm{~m}, 2 \mathrm{H}) ; 7.33(\mathrm{~m}, 4 \mathrm{H}) ; 7.46(\mathrm{~d}, 1 \mathrm{H}, J=2.2 \mathrm{~Hz})$; $7.85(\mathrm{t}, 2 \mathrm{H}, J=8.9 \mathrm{~Hz}) ; 7.91(\mathrm{~d}, 1 \mathrm{H}, J=8.2 \mathrm{~Hz}) ; 8.22(\mathrm{~s}, 1 \mathrm{H}$, $\mathrm{H}(5)) .{ }^{31} \mathrm{P}$ NMR (DMSO-d 6 ), $\delta: 3.7$. 
Addition of diethyl phosphite to $\mathrm{N}$-benzylideneaniline. Recyclization of the catalyst. Diethyl phosphite $(2.4 \mathrm{mmol})$ was added to a solution of benzylideneaniline $(2 \mathrm{mmol})$ and the catalyst $\mathbf{6 a}$ or $\mathbf{6 b}(0.2 \mathrm{mmol})$ in toluene or dichloromethane $(1.5 \mathrm{~mL})$. The mixture was stirred at room temperature for the time necessary for the reaction to reach completion (TLC monitoring, eluent: hexane-AcOEt, $5: 2$ ). Then, the reaction mixture was treated with $\mathrm{Et}_{2} \mathrm{O}$, a catalyst that precipitated was filtered off and washed with $\mathrm{Et}_{2} \mathrm{O}$. The ethereal solution was concentrated in vacuo, an oil that obtained was studied by ${ }^{31} \mathrm{P}$ NMR spectroscopy to determine the yield of diethyl phenyl(phenylamino)methylphosphonate (7).

The catalyst $6 \mathbf{a}$ or $\mathbf{6 b}$ was dried in vacuo and reused according to the procedure described above.

Diethyl phenyl(phenylamino)methylphosphonate (7) ${ }^{26}$. Colorless oil. ${ }^{1} \mathrm{H}$ NMR $\left(\mathrm{CDCl}_{3}\right), \delta: 1.12(\mathrm{t}, 3 \mathrm{H}, J=7.3 \mathrm{~Hz}) ; 1.28$ (t, $3 \mathrm{H}, J=7.3 \mathrm{~Hz}$ ); 3.70 (br.s, $1 \mathrm{H}) ; 4.02$ (q, $4 \mathrm{H}, J=6.7 \mathrm{~Hz})$; $4.57\left(\mathrm{~d}, 1 \mathrm{H} J_{\mathrm{PH}}=23.6 \mathrm{~Hz}\right) ; 6.51-6.67(5 \mathrm{H}, \mathrm{Ar}) ; 7.55-8.17$ (5 H, Ar). ${ }^{31} \mathrm{P}$ NMR $\left(\mathrm{CDCl}_{3}\right), \delta: 21.8$.

This work was financially supported by the Russian Foundation for Basic Research (Project No. 08-03-92505).

\section{References}

1. A. N. Pudovik, Dokl. Akad. Nauk SSSR, 1952, 83, 865 [Dokl. Chem. (Engl. Transl.), 1952].

2. M. Ordornez, H. Rojas-Cabrera, C. Cativiela, Tetrahedron, 2009, 65, 17.

3. L. Albrecht, A. Albrecht, H. Krawczyk, K. A. Joergensen, Chem. Eur. J., 2010, 16, 28.

4. J. Zon, Pol. J. Chem., 1981, 55, 643.

5. S. Laschat, H. Kunz, Synthesis, 1992, 90.

6. C. Yuan, Sh. Li, G. Wang, Y. Ma, Phosphorus, Sulfur Silicon Relat. Elem., 1993, 81, 27.

7. B. C. Ranu, A. Hajra, J. Jana, Org. Lett., 1999, 1, 1141.

8. J. S. Yadav, B. V. S. Reddy, K. Sarita Raj, K. Bhaskar Reddy, A. R. Prasad, Synthesis, 2001, 2277.
9. E. Haak, I. Btschkov, S. Doye, Eur. J. Org. Chem., 2002, 457. 10. S.-K. Chung, D.-H. Kang, Tetrahedron Asymm., 1996, 7, 21.

11. H. Sasai, S. Arai, Y. Tahara, M. Shibasaki, J. Org. Chem., $1995,60,6656$.

12. T. Akiyama, H. Morita, J. Itoh, K. Fuchibe, Org. Lett., 2005, 7, 2583.

13. R. Zimmer, V. Dekaris, M. Knauer, L. Schefzig, H.-U. Reissig, Synth. Commun., 2009, 39, 1012.

14. D. E. Bergbreiter, J. Tian, Ch. Hongfa, Chem. Rev., 2009, 109, 530 .

15. D. Cai, R. D. Larsen, P. J. Reider, Tetrahedron Lett., 2002, 43, 4055.

16. H. Hocke, Y. Uozumi, Tetrahedron, 2003, 59, 619.

17. H. Sasai, T. Tokunaga, S. Watanabe, T. Suzuki, N. Itoh, M. Shibasaki, J. Org. Chem., 1995, 60, 7388.

18. J. Andersen, U. Madsen, F. Björkling, X. Liang, Synlett, 2005, 2209.

19. S. L. Jain, J. K. Joseph, F. E. Kühn, O. Reiser, Adv. Synth. Catal., 2009, 351, 230.

20. N. Kaval, D. Ermolat'ev, P. Appukkuttan, W. Dehaen, C. O. Kappe, E. van der Eycken, J. Comb. Chem., 2005, 7, 490.

21. R. Lucas, V. Neto, A. H. Bouazza, R. Zerrouki, R. Granet, P. Krausz, Y. Champavier, Tetrahedron Lett., 2008, 49, 1004.

22. M. van Dijk, M. L. Nollet, P. Weijers, A. C. Dechesne, C. F. van Nostrum, W. E. Hennink, D. T. S. Rijkers, R. M. J. Liskamp, Biomacromolecules, 2008, 9, 2834.

23. C. Haensch, T. Erdmenger, M. W. M. Fijten, S. Hoeppener, U. S. Schubert, Langmuir, 25, 8019.

24. S. Varray, R. Lazaro, J. Martinez, F. Lamaty, Organometallics, 2003, 22, 2426.

25. R. Kulbokaite, G. Ciuta, M. Netopilik, R. Makuska, React. Funct. Polymers, 2009, 69, 771.

26. M. Kasthuraiah, K. A. Kumar, C. S. Reddy, C. D. Reddy, Heteroatom Chem., 2007, 18, 2. 